\title{
COMPARATIVE STUDY IN EX-SOVIET UNION STATES REGARDING RESTITUTION/COMPENSATION
}

\author{
SAIDA BEJTJA (MUCA), DRITAN BEJTJA
}

\begin{abstract}
:
The aim of this paper is to analyze the transformations that occurred in the area of private property ownership following the change of political regime in former socialist or communist countries. The six countries looked at are: Estonia, Latvia, Lithuania, Ukraine and Russia. These countries illustrate well the whole range of contentious problems in a region where the Communist regimes have varied tremendously in their approach to private property, intensity of social control, repression and overall legitimacy. This diversity of situations poses today different types of dilemmas for the property restitution process, dilemmas which are approached by each country in a different manner. The main question for the countries is how an emerging democracy can "respond to public demands for redress of the legitimate grievances of some without creating new injustices for others." Moreover, property rights and transparency represent the very bases of a functioning market economy: each of the countries faces the difficult task of finding a balance between remedying violations of property rights and guaranteeing a functioning land market, which enables or will enable full freedom of movement of capital in the EU. There are a number of fundamental difficulties and dilemmas regarding nationalization and restitution/compensation policies in the post-Communist governments in Estonia, Latvia, Lithuania, Ukraine and Russia had to face.
\end{abstract}

\section{Keywords:}

property, restitution, rights, dilemmas, process

JEL Classification: K11, K11, K11

\section{Authors:}

SAIDA BEJTJA (MUCA), Aleksander Xhuvani" University, Faculty of Economics, Department of The right, Elbasan, Albania. E mail: saida.muca@live.com, Elbasan, Albania, Email: saida.muca@live.com DRITAN BEJTJA, "Aleksander Xhuvani" University, Faculty of Economics, Department of Business -Administration, Elbasan, Albania. E mail: dbejtja@live.com, ELBASAN, ALBANIA, Email: dbejtja@live.com

\section{Citation:}

SAIDA BEJTJA (MUCA), DRITAN BEJTJA (2015). Comparative Study in ex-Soviet Union States Regarding Restitution/Compensation. International Journal of Social Sciences, Vol. IV(3), pp. 1-19., 10.20472/SS.2015.4.3.001 


\section{Country-by-Country Summary of Property Restitution}

\section{Estonia}

- Private property claims generally resolved.

- Communal property returned.

\section{Private Property}

Private property owners who filed their claims before the appropriate deadline have been able to reclaim their property, irrespective of present citizenship. Title to heirless property passes to the local municipal administration of the area in which the property is located. The administration is free to sell the property or retain it for its own use.

Property restitution in Estonia was carried out under the Principles of Ownership Reform Act that was passed on June 13, 1991, and has been largely completed.

\section{Communal Property}

Most Orthodox Church properties, including those in use by the Estonian Orthodox Church -Moscow Patriarchate (EOCMP), were under the legal control of the Estonian Apostolic Orthodox Church (EAOC). The Government transferred seven properties to the EOCMP in 2005-2006, and the three remaining properties in 2006-2007.

According to leaders of the Estonian Jewish community, property restitution has not been an issue for the community, since most prewar religious buildings were rented, not owned.

\section{Latvia}

- In November 2006, Parliament rejected a property restitution bill that would have provided compensation for or the restitution of communal and heirless property to the Jewish community. The community and the World Restitution Organization are considering alternative proposals.

\section{Private Property}

Two 1991 laws provide for the restitution of confiscated property, both private and communal, to former owners or heirs. The law does not discriminate on the basis of citizenship or residency. In most cases, municipal authorities make the final decision on property restitution; if they deem a property non-returnable, they may offer alternative property or compensation in the form of vouchers. Claimants, however, may be reluctant to accept alternative property because of the difficulty in establishing comparative values. Claims for private property occupied by economically productive facilities have been particularly difficult to resolve.

\section{Communal Property}

In November 2006, the Government of Latvia introduced legislation to return to the Jewish community property owned by the community prior to World War II, or to provide compensation if return of the property was not practical. The legislation would have also provided compensation to the community for property belonging to individuals known to have died without heirs during the Holocaust. The legislation contained a list of over 200 properties which the Jewish community 
and the government agreed should be returned, or for which compensation should be paid. Although the newly installed Government supported the legislation, the parliament failed to approve the legislation in first reading. As of September 1, 2007, the government had not made a decision on how it wishes to proceed on this issue.

Until now, Jewish communal property restitution had been limited to the return of religious properties to the small observant community, but not to the significantly larger non-observant community. The observant Jewish community has received 16 religious properties and compensation for two others.

Prior to World War II, the Jewish community of over 100,000 held 72 synagogues and 136 preaching houses. Approximately 70,000 Latvian Jews died in the Holocaust.

Non-Jewish communal property confiscated during World War II has generally been returned, although some claims remain outstanding.

\section{Lithuania}

- Lack of alternative property with which to compensate claimants delays private property restitution.

- Government developing communal property law.

\section{Private Property}

The Lithuanian government has restituted to private claimants most of the property that can be returned. Resolution of the remaining private property claims will require the identification of alternative property or the payment of compensation, estimated at approximately 500 million USD (see below for details). The GOL-established deadline for paying compensation for land, forest, and bodies of water is 2009, and 2011 for houses and apartments.

Under the current program the Lithuanian Finance Ministry may pay compensation only to Lithuanian citizens, but citizens qualify regardless of their place of domicile. Until recently, dual citizenship was not recognized for ethnic Russians, Poles, and Jews who emigrated from Lithuania to a country considered an ethnic homeland. For example, Lithuanian Jews who emigrated to Israel or Lithuanian Poles who emigrated to Poland lost their Lithuanian citizenship. This was challenged in the court system. The Constitutional Court ruled in 2006 that, according to the Constitution, dual citizenship should only be allowed in limited cases. There is widespread popular support for dual citizenship and there may be a referendum to amend the constitution. For now, however, those who had dual citizenship may retain it, but under current law it will only be allowed in special circumstances.

Citizenship limitations coupled with near extermination of the Lithuanian Jewish population during the Holocaust means that the vast majority of the thousands of private properties owned by Lithuanian Jews prior to the Soviet and Nazi occupations were never restituted.

The GOL-established deadline to submit applications for property restitution was December 2001. The GOL's deadline to prove kinship to the original owner was December 31, 2002. During the application period, from 1991 through 2001, the Lithuanian government received approximately 9,500 claims for private houses and over 57,000 applications for the return of land. In March 2002, the Parliament amended the restitution law to provide that restitutable land not being used 
for public purposes and located in urban areas must be returned to its former owners.

The Government is legally obligated to compensate by 2009 private land owners whose land will not be restituted in kind. The Government is obligated to restore ownership rights to or to compensate house or building owners as well as compensate religious communities by 2011 . The total obligation of the state is estimated at 2.3 billion litas (approximately 0.9 billion USD). Through January 1, 2007 the Government allocated 1.6 billion litas ( 0.6 billion USD) for the above mentioned compensations. Approximately one-third of allocated funds (507 million litas; 200 million USD) comes in the form of shares in large, state-owned energy, telecom, and shipping companies.

For 2007, the national budget provides 171 million litas (68.4 million USD) for compensation in relation to land restitution, and 72 million litas (28.8 million USD) for restitution of property rights to house owners and compensation to religious communities. Of these 72 million litas, religious communities will receive 5.3 million litas (2.1 million USD). In 2006, compensation to religious communities amounted to 15.6 million litas (6.2 million USD), 3 million litas (1.2 million USD) in 2005, and 1.6 million litas (0.6 million USD) in 2004.

\section{Communal Property}

A 1995 law permits only registered religious groups (as opposed to secular groups) to apply for the restitution of religious property. Several religious groups received properties. The Evangelical Reform Church as well as the Jewish community assert that many of the properties they held prior to WWII have not been restituted. From 1991 to 1996, Jewish communities claimed and received a total of 28 buildings, mostly synagogues (three in Vilnius, five in Kaunas and the balance in small towns).

In June 2002, a government commission, comprised of cabinet ministers, commenced a review of Jewish communal property (property owned jointly by the Jewish community, but not considered "religious" property and, thus, not eligible under the earlier religious property restitution process). Lithuanian and international Jewish groups developed a list of unrestituted Jewish communal properties throughout the country and submitted the list to the Government. These Jewish organizations formed a foundation to assist in managing restituted property and in aiding Jewish citizens in pursuing claims.

In September 2002, the government drafted amendments to the existing property restitution law. The amendments would change the 1995 law to broaden the definition of religious property to include Jewish communal property. The amendments would not change the current restriction that prohibits religious groups from receiving restitution for property without buildings. Similar amendments were considered again in early 2006, but progress was slowed by the collapse of the governing coalition. There are ongoing discussions between Jewish groups and the Government about the possibility of introducing communal property restitution legislation to Parliament in the fall of 2007.

In September 2002, the Lithuanian Government approved a plan to restore parts of the historical Jewish quarter in Vilnius. Plans included the restoration of commercial buildings, such as service offices and workshops, hotels, and residential buildings. Originally scheduled for completion in 2008 , the project has received no funding since the initial planning phase. The Vilnius municipal government has moved forward with plans for a Jewish Cultural Center in the area and is working with the local Jewish community on that and other potential projects. Overall, however, the 
original, ambitious plans are on hold.

\section{Ukraine}

- Ukraine has no legislation governing the restitution of private property.

- Many places of worship have been restituted but the resolution of more complex restitution cases remains slow.

\section{Private Property}

Ukraine has no laws or decrees governing the restitution of private property, nor has the government made any proposals in this regard.

\section{Communal Property}

Ukraine has no state religion. The Ukrainian Orthodox Church - Moscow Patriarchate (UOC-MP), Ukrainian Orthodox Church - Kyiv Patriarchate (UOC-KP) and the Ukrainian Greek Catholic Church are the predominant religious organizations. These churches can exert political influence at both the local and regional levels, and most religious groups allege that local governments discriminate in favor of the predominant religion of the region.

Registered religious organizations are the only entities permitted to seek restitution of property confiscated by the Soviet regime, and restitution is generally limited to buildings and objects immediately necessary for religious worship. A 1992 decree commenced Ukraine's restitution program for religious buildings. In August 2007 the Interagency Commission on Restitution of Property to Religious Organizations instructed the Ministry of Justice and State Committee for Nationalities and Religions (SCNR) to draft a law on restitution of property to religious organizations.

The slow pace of restitution was partly a reflection of the country's economic situation, which limited funds available to relocate occupants of seized religious property. Most groups asserted that there was slow progress in the restitution of property. However, the SCNR has now declared that the majority of buildings and objects in question have been returned to religious organizations and that many of the remaining properties for which restitution was being sought were complicated by that fact they were occupied by state institutions, were historic landmarks, or were previously transferred to private ownership. The SCNR also noted that restitution claims frequently fall under the jurisdiction of local governments. All major religious organizations called on the Government to establish a transparent legal process to address restitution claims.

In October 2006, with the urging of representatives of various denominations, Prime Minister Viktor Yanukovych called for the resumption of activity of the Interagency Commission on Restitution of Property to Religious Organizations. The commission, established in 2002 but active only intermittently, resumed its work in March 2007. The commission's primary goal was to return property to religious communities, and it took 316 restitution cases under consideration. Some observers expressed concerns about its effectiveness and the transparency of its procedures. According to the government, 3, 600 religious properties and more than 12,000 religious items were transferred-in ownership or in usage-to religious organizations between 1992 and 2006. In July 2007 the SCNR estimated that religious organizations of all denominations had $68.9 \%$ of the required number of houses of worship. Between 1992 and 2004, government funds and donations were used to rebuild or construct 4,398 places of worship. However, Jewish and 
Baptist groups have complained that such funding has been allocated for Orthodox Church buildings only.

Intra-communal competition for particular properties complicated the restitution issue for Christian, Jewish, and Muslim communities. For example, the UOC-MP and UOC-KP have not resolved differences concerning the Holy Trinity Church in Rokhmaniv Village in Ternopil Oblast despite an August 31, 2006, ruling by the High Administrative Court that overturned a 2005 resolution by the Ternopil Region State Administration that parishioners of the two churches should share the church on a rotational basis. On June 22, 2007, while commenting on the events in Rokhmaniv, the Chairman of the SCNR stated that although he hoped to see an end to the practice of various denominations sharing a house of worship, the Government should not intrude into interdenominational disputes.

Representatives of the UOC-KP complained that local authorities in Kyiv ignored its requests for return of a former monastery building at Tryokhsvyatytelska St. to the St. Michael's Monastery.

The Government has not transferred ownership of St. Nicholas' Cathedral and a former residence of bishops in Kyiv to the Roman Catholic Church. However, the Church was permitted to use the cathedral for daily morning Mass, on weekends, and during major religious holidays. Church representatives also expressed frustration about unrealized restitution claims of buildings formerly belonging to St. Oleksander's Church in Kyiv, which they stated were improperly privatized in the 1990s, as well as in Chernivtsi, Dnipropetrovsk, Lviv, Mykolayiv, Sevastopol, and Simferopol. The Government continued to refuse to facilitate the restitution of Odesa's Roman Catholic seminary, which was confiscated by the Soviet regime.

Ukrainian Greek Catholic Church leader Cardinal Huzar told the press that authorities in Lviv had not returned its former premises adjacent to the St. George's Cathedral in Lviv. Local officials declared that the Government did not have the money to resettle more than a dozen families residing there since Soviet times.

According to Bishop Bronislav Bernatsky, the Government continued to refuse to facilitate the restitution of Odesa's Roman Catholic seminary, which was confiscated by the Soviet regime.

Jewish community representatives report that some progress has been made, on the restitution of Jewish communal properties, although the process is slow. Competing claims by different Jewish groups is a complicating factor. Muslim community leaders have also complained of unresolved restitution claims involving several mosques. For example, representatives of the Muslim community asserted that the Government's slow pace of communal property restitution undermined the authority of moderate Muslim leaders. Muslim community leaders complained in particular about unresolved restitution claims involving a 118-year-old mosque in Mykolayiv, a famed mosque in Dnipropetrovsk, a 150-year-old mosque in the Crimean town of Masandra, a mosque in Yalta, and the ruins of an 18th-century mosque in the Crimean coastal city of Alushta.

There were some positive developments in 2007 in resolving long-standing restitution claims. For example, in May the Prosecutor General's Office dropped its investigation into claims that the AllUkraine Baptist Union had illegally acquired its headquarters in downtown Kyiv. In February 2007, Odesa's Presbyterian community won a court ruling on the local actors' guild effort to gain ownership of the recently renovated historical Presbyterian Church building, and the actors' guild appeal of the verdict was overruled. 


\section{Russia}

- 4000 communal property buildings returned.

- Religious organizations continue to pursue claims.

\section{Communal Property}

Despite considerable progress in this area since 1991, a number of religious communities remain concerned about unrestituted religious property confiscated during the Soviet era. According to the Presidential Administration, the Russian government's Restitution Commission returned approximately 4,000 buildings between the time the decree on communal property restitution went into effect in 1993 and March 15, 2001 when Prime Minister Kasyanov ordered the commission to cease its activities.

Approximately 3,500 of the restituted buildings were returned to the Russian Orthodox Church. Smaller numbers of buildings and houses of worship were returned to non-Orthodox Christian, Jewish, and Muslim communities. While the Russian Orthodox Church has had the most success in securing restitution, the Ministry of Culture has not restored to the Church full control over several of its most high profile properties. For example, Moscow's Kremlin cathedrals (St. Petersburg's Peter and Paul Cathedral, and Vologda's Archbishop's Courtyard) remain state-run museums. Two large museum complexes -- Solovetskiy Monastery and Ryazan Kremlin - have been returned. The Russian Orthodox Church continues to claim 44 monasteries, 12,665 parishes and two million hectares of land.

The Federation of Jewish Communities of Russia reports that federal officials generally have been cooperative in the community's efforts to seek restitution of former community property; the level of cooperation of regional and local officials varies from region to region. One obstacle to restitution is the need to find new premises for organizations currently housed in former religious buildings.

Examples of restitutions to the Jewish community include a synagogue in Oryol in 2003, and in 2004-2005 a synagogue in Vladivostok and school buildings in Rostov-on-Don and Orenburg. Even with these modest successes, the Jewish community faces the same obstacles as other religious communities in obtaining the restitution of properties seized during the communist era. Some in the Jewish community assert that only a small portion of the total properties confiscated under Soviet rule has been returned.

The Moscow Diocese of the Russian Orthodox Church (ROC) has been quite successful in restituting properties. The ROC now owns more than 1400 buildings, compared to 130 in 1998. Property claims for the ROC are legally complicated, since there was no separation of church and state before the revolution. Most of the Orthodox Church buildings that have been returned to the ROC were not considered ROC property before 1917. The ROC was only entitled to use these buildings. The ROC now owns only churches built, bought, or received after 1991.

The Roman Catholic Community reports 44 disputed properties, most of which were used for religious services. While most state-owned property has been returned, the community has had no success with buildings that have been privatized. For example, an oil company currently occupies the Saint Peter and Saint Paul cathedral in Moscow and the Catholic parish is meeting in a former disco hall. The Church is making some progress toward building a new Catholic Church in Moscow to replace the cathedral. In Vologda, Catholic authorities have not succeeded 
in achieving restitution of a pre-revolution church that now houses a restaurant. In March 2004, Tula City Duma Deputies returned a church to the local Catholic community. The church was officially given to the Tula Catholic community in 1994, but the building was occupied by a forensic medical practice until 2003.

The St. Petersburg Russian Orthodox Old Believers' Community has not been able to re-obtain its church building, which Soviet authorities confiscated in 1922, only 7 years after the community purchased it. In a positive development, an Old Believer community in Samara has regained its pre-Revolution

church.

The Russian government has returned approximately 15,000 religious articles, including icons, Torahs and other items, to religious groups. Many other religious artifacts, however, remain in state museum collections.

Although Russia passed a law in 1997 proclaiming that all captured foreign cultural objects from World War II were property of the Russian Federation, the law permits the restitution of three important categories of property: (a) objects that originally belonged to countries that were themselves victims of Nazism; (b) objects that were the private property of individuals persecuted by the Nazis on racial or political grounds, and (c) cultural artifacts that belonged to churches and religious organizations that did not serve the political of military interests of the Nazis.

In 2005, Russia returned the Sarospatek library collection to a Catholic educational institution in the Czech Republic. An interagency council is reviewing Hungarian claims for archives. Two American claims remain to be reviewed.

The international Chabad Lubavitch organization as well as the U.S. Government has repeatedly sought return of the Schneersohn Collection, a large collection of revered religious books and documents of the Lubavitcher rebbes. The government has rejected this request, maintaining that the Collection is part of Russia's cultural heritage.

\section{Some conclusions regarding the Field of the Cadastral Accounting and Registration of Property Rights in Russia.}

It is difficult to overestimate the importance of real estate for political, economic and legal system of Russian society.

Land and other real estate are a powerful economic resource which, firstly, has not been used by the Russian economy efficiently, and, secondly, the economic potential of which is greatly underestimated.

The researches of some economists rather convincingly prove the hypothesis according to which one of the main causes of economic gap between the developed European countries and the countries of the third world is inability to properly use the resources available in such countries.

This "inability" consists in the absence of the conditions providing protection of the rights to resources and free circulation of the rights thereto. If the property rights are not protected or not established at all, the property turns into "the dead capital" which cannot be used for securing of attracted financial resources, creation of the derivatives. As a result - "undercapitalization" of individual companies and of the national economy as a whole. 
As the Russian economy develops, the property turnover becomes more and more intensive every year.

That is why every day economic and public management agents make higher and higher demands to quality and accessibility of services in the field of property rights registration.

It is worth noting that the country is facing an ironic situation: Despite the rapid development of the civil property turnover which started before 1997, the property rights to a considerable part of real estate objects are still not registered.

It is believed that one of the main reasons here is great time and financial costs associated with the property rights registration.

Successful achievement of important economic objectives depends on effective functioning of the property rights registration and cadastral accounting system.

In particular, there is a task of acceleration of the state property rights registration within the privatization process.

Details of the property Cadastre are necessary for territorial planning and town-planning zoning, architectural (building) designing, keeping registers of state and municipal property, state and municipal property management.

Availability of actual and full information on property is of great importance to the mass property assessment and taxable base calculation, including in the situation when the uniform property tax is introduced.

The ability of individuals and organizations to attract credit resources directly depends of the efficiency of the rights registration and accounting system because good timing of receiving relevant information on the property rights plays a key role here.

The quality of accounting and registration system functioning affects not only the stability of the civil immovable property turnover, but also the trust to the state institutes, the investment appeal of the Russian Federation The accounting and registration system development level is of great importance to Russia in terms of creating its reputation and is a subject of international monitoring.

Despite a number of crisis phenomena in the world economy, the immovable property turnover in Russia not only hasn't decreased but also has increased.

The Russian State Register is an establishment which is high on the list in terms of the amount of rendered state services and volume of interdepartmental cooperation.

The Russian State Register agencies admit almost half a million applications daily. About $80 \mathrm{mln}$ account and registration operations are completed annually.

So far the quality of the rendered services leaves much to be desired. The system throughout does not satisfy the existing demand for services. As a result, a number of regions are facing long lines, unreasonable refusals, and corruption. 
The Russian accounting and registration system has not reached the same level of the advanced systems development as in some of the European states, and that is why it regularly is exposed to fair criticism. But they must bear in mind that their history of development dates back hundreds of years.

For example, in Germany a legislative framework for the registration system was provided for the first time in 1794. At the present moment, the Russian system of the cadastral accounting and registration is at its final stage of building up.

In 2008, the Ministry started consolidation of three registration systems: land cadastre system, property rights registration system and system of technical accounting of buildings and structures.

Now, the implementation of the Unified System Creation Concept confirmed by the Ministry in December 2009 is near completion.

Comparing to what they had before, the Russian accounting and registration system is gradually taking a new form, a new quality status.

Earlier, when they had three separate systems, rightsholders had to go through at least three procedures, to collect information from three sources, and this were engaged in synchronization of three information resources, hurrying and scurrying around with their documents from office to office.

With a view of unifying the land Cadastre system and the property rights registration system, the Russian State Register was established on the basis of the Federal Agency for the Cadastre of Real Properties and the Federal Registration Service, which made it possible to simultaneously submit applications for cadastral accounting and property rights registration.

In order to unify the cadastral accounting system with the system of technical accounting of buildings, structures and premises, the stage-by-stage transfer of registration functions from the Technical Inventory Bureau to the Land Cadastral Chamber is almost completed. At the same time, the large-scale work on transferring the data from the Technical Inventory Bureau to the State Immovable Property Cadastre is proceeding to its completion.

So far, information on $132 \mathrm{mln}$ immovable property units has been included into the Cadastre all over the Russian Federation.

On average, the share of the Russian State Register E-services among other types of services is about $20 \%$. In some regions, up to $40 \%$ of the data from the property rights register and up to $30 \%$ of the data from the Cadastre are provided in electronic form through the Internet. The public cadastral card is very popular among individuals and companies.

According to the annual Doing Business investment appeal rating, in 2012 Russia ranked 45th (out of 183 countries) on the subindex "Immovable Property Registration" which is far ahead of its positions on other subindexes and 6 point higher than in 2011.

Development of the Russian economy not only requires that the accounting and registration system forming be completed in a quite short time but also tries to make it one of the best in the world, to improve it for the sake of comfort and convenience of services for individuals and companies. 
In order to achieve this goal as soon as possible, they surely need to continue to pursue the same serious approaches (both organizational and innovative), and to implement well-defined HR policy.

They need:

- firstly, to form the reliable Unified Register of Property Rights containing consistent and full information both about the rights and about all necessary characteristics of immovable property units, protective and security zones limits;

- secondly, to reduce the term of cadastral accounting and registration of the rights to one week;

- thirdly, to introduce new technologies of online interaction with applicants, particularly, to minimize paperwork and to provide almost all services online. This being said, comfortable conditions of rendering services without the Internet must also be created;

- fourthly, to raise the status, remuneration of registering clerks and to enlarge the scope of their responsibilities for committed actions. It is necessary to raise the quality of training of registering clerks, particularly, to create an educational cent on the basis of one of federal institutions;

- fifthly, to create effective mechanisms of damage compensation in full in case of immovable property loss and (or) other risks;

- sixthly, to provide for overall performance and responsibility of cadastral engineers;

- seventhly, to raise awareness of individuals and companies with regard to the accounting and registration system capability, new ways and forms of rendering services.

As a result, it is necessary to provide for a high level of the registered rights guarantees, to eliminate administrative barriers and corrupt practices; in general, to improve the quality of rendered services, to make the accounting and registration system more "friendly", "clear" for everyone.

They have finished elaboration of the "road map" project aimed at optimization of immovable property registration procedures which will be soon put before the Government for consideration.

Today I suggest to give a general characteristic to the current situation, outline the key system issues and define the key measures aimed at tackling the problems taking into account the "road map" project. 


\section{Case study: LAMP in Albania}

\section{Security of Tenure and Registration of Immovable Property Rights}

\section{Re-engineering of office functions and quality improvement}

This sub-component supported the Immovable Property Registration Office (IPRO) in enhancing their management effectiveness, improving human resources policies, and also improving its service delivery and transparency. It included the re-engineering of the workflow in IPRO, the re-design of business processes through the introduction of more rigorous systems of case management and quality control, and business/human resource planning. This sub- component also supported the remedial work required to bring existing kartela and cadastral map information up to the prescribed standards.

- The re-engineering of office functions and quality improvement were linked closely with the ICT sub-component. ALBSReP (Real Estate Electronic Database, administered by the Immovable Properties Registration Office) is the fully automated system with internal controls for case management and quality control components. The IPRO drafted detailed Instructions for use of ALBSReP to maintain new first registration data. With regard to improving existing data, the new registration law approved in March 2012 included a provision for initiating the process and more detailed procedures and regulations were under development, but not completed at the end of the project. The general regulations are planned to be completed by May 2015.

- Significant institutional changes have been implemented. The IPRO became a selffinancing agency as of April 1, 2013. In order to support the new structure a Strategic Business Plan (SBP) was developed through a Sida Twinning project. The IPRO Steering Board approved the final version of the SBP. The importance of adopting the SBP is highlighted by the fact that IPRO had to return over US\$5 million to the State Budget for 2013 because it did not have the funds allocated to properly planned activities for the much needed investments. Key highlights of the Strategic Business Plan include:

\section{IPRO Business Aim:}

IPRO registers immovable properties, ownership titles and other real rights, maintains and administers the register of properties, the cadastral maps and legal documentation, which proves ownership rights of citizens, natural and legal persons, in order to assure legal certainty in relation to the immovable property actions.

\section{IPRO Vision 2018:}

IPRO, as a self-funded and client-oriented organization administers and guarantees full, accurate, sustainable and up-to-date registration of immovable property information, and it provides geospatial information and other related services. Products and services are provided with effectiveness, efficacy, in a transparent and non-discriminatory manner. IPRO through its products and services, in line with the EU standards and best international practices contributes

to the building and stability of the real estate market and it therefore supports the social and economic development of Albania.

\section{Strategies:}

- Provision of standard qualitative data for all the properties. 
- Improvement of client-oriented services.

- Improvement of the management system and building of technical capacities of the staff.

- Extension of the scope of activities.

\section{Objectives:}

- Provision of standard qualitative data for all the properties

- Completion of initial registration of all the cadastral zones until the second quarter of 2014.

- Completion of initial registration of all the remaining cadastral zones until the fourth quarter of 2016.

- Functioning of ALBSReP in 10 big offices, until the second quarter of 2014.

- Functioning of ALBSReP in remaining offices, until the fourth quarter of 2015.

- The information found in IPRO is improved and updated to meet the requirements foreseen by law 33/2012 and as such, they may be used in the ALBSReP system within the fourth quarter of 2018.

- Improvement of client-oriented services

- Reduction of the time period of provision of services for the services of $x \%$ until the fourth quarter of 2016.

- Setting up of the focus groups for seven big segments of the market according to Chapter 5.4 within the first quarter of 2014.

- Client Satisfaction Survey must indicate that more than $70 \%$ of clients are "satisfied" or "very much satisfied" within the fourth quarter of 2016.

- Legitimate facilitators are provided with access to the existing information in the online ALBSReP system within the fourth quarter of 2014.

- Improvement of the management systems and building of technical capacities of the staff

- Reconstruction/Construction of local offices with the proper infrastructure, in line with the economic standards of the offices, within the fourth quarter of 2018.

- Installation of the Financial Management System, including the Financial Management Manual and Software within the fourth quarter of 2014.

- Imposition of the Performance Indicators for the work processes, services, staff and drafting of performance assessment methodology within the second quarter of 2015.

- Preparation of the regulatory framework of human resources and drafting of the long-term training strategy within the second quarter of 2014.

- Design and installation of intranet within the second quarter of 2017.

- Extension of the scope of activities

- ALBPOS made operational and maintenance within the second quarter of 2014.

- ALBPOS business plan completed within the second quarter of 2014 .

- Structure and necessary capacities for valuation of properties within the fourth quarter of 2017. 
- Interface of the Civil Register, Address Register and other valid databases within the fourth quarter of 2014.

- The Prime Minister's Office is now overseeing improvements to key agencies across the public sector, including IPRO. Set of deliverables within a 100 and 300 days has been delivered to the Prime Minister's Office from IPRO. These deliverables have been directly derived from the Strategic Business Plan.

- The implementation of the ALBSReP solution and the proposed implementation of a onestop-shop by the Prime Minister's Office provides IPRO with the opportunity to rationalize the District Office network of 35 offices and create centralized service centers to process the transactions. This would lower the costs of operations and reduce the capacity building issues in District Offices.

\section{Information Technology Development.}

The sub-component supported the further implementation of automated systems to support the re-engineered workflow and the IPRO Registration Automation Strategy. The implementation focused on the larger urban district offices. The project also financed data conversion, data improvement and the creation of digital archives of key property records. The target of this sub-component was to fully computerize ten IPRO district offices. This means i) connectivity and networking with the central office; ii) integration of software and hardware, iii) data migration and iv) trained and competent staff capable to use and maintain the system.

- By the end of the project in June 30, 2014 the ICT system (ALBSReP) was in operation 17 District Offices (including Tirana, Durres, Elbasan, Fier, Shkodra, Laç, Lezhe and Lushnje), despite a delay of more than a year due to the lack of a contract for communication lines to connect the 10 largest local offices with the main data center in Tirana. This ICT solution includes the scanned digital archives and scanning of incoming documents in the larger 11 offices. Progress has been made in completing the indices of the scanned documents with missing indices (about $15 \%$ of

documents were not properly indexed - close to 2 millions documents). This has been reduced to $2.8 \%$ of scanned documents. By October 31, 2014, ALBSReP had been installed in all 35 District Offices to support the front and back office functionalities to maintain the first registration data and there is a central database that manages the data from all 35 offices.

- Online services to the notaries is fully operational and a new service layer had been developed to provide all types of information (scanned documents, alphanumeric and graphical) to key external users, subject to signed agreements and based on the existing legal regulations. The system is ready to share information with key government registers, such as civil register, business register and tax register. Gender disaggregated data has been generated from the new IT system; this is an additional achievement.

- The ICT system (ALBSReP) and its development have been a key success in this project. Some of the key success factors have been:

- Software Development Team composition: The software development team had a clear structure and was led by a senior software development team leader 
and clear planning and reporting mechanisms were on place. The local software development team was supported by an international quality assurance expert (responsible for system quality assurance, capacity building as well as advising the decision makers on the progress, key issues and possible solutions) and a senior solution architect (responsible for design of the system architecture and technical platform, including oversight of supply of hardware and integration). In addition there was a twining project that SIDA financed, during the inception phase that strengthened the system design.

- Rational Unified Process (RUP) methodology: RUP was selected and introduced to manage the ICT system design and development and was strictly followed right from the beginning.

- Adoption of International Standards: The ALBSReP solution was the first in Europe to adopt the Land Administration Domain Model (LADM) ISO standard.

o System Documentation: The ALBSReP solution has been fully documented by the system developers.

○ Three level ICT management structure: This effective structure was established from the beginning with clear reporting mechanism (decision making body, project manager and working groups and contractors plus quality assurance advisors).

- Training and capacity building: Capacity building of the IT team was an integral part of planned program and regularly provided through on the job training, provided by the quality assurance expert.

o IPRO IT Directorate structure: The IT Directorate was reviewed and reorganized in a modern and effective way. The Software Development Unit was established and staff hired. The Maintenance and Support Unit was strengthened with two additional system and DB administrators to create effective sustainability of the unit.

- High-level political support: This top-level support ensured adequate resources and enforced excellent communications.

- Excellent Stakeholder Engagement: Regular video-conferencing and meetings during the supervision missions were organized with the members of the decision making body (mainly with the Deputy Minister of Ministry of Innovation and ICT, the prime minister adviser on ICT and the Director of Agency for Information Technology), IPRO IT project manager and the Bank team followed up on the progress and efficiently resolved any critical issues.

- Clarity on Roles \& Responsibilities: The IPRO board has approved the IPS Security Instruction. This is a very important document that details who has access to which part of the system and what are their roles and responsibilities.

- No progress was made in finding a temporary solution for the Disaster Recovery Center. This will now wait until the Ministry of Innovation completes their disaster recovery center for all government institutions; a feasibility study is currently performed. The ALBSReP system is fully centralized (both instances of the ALBSReP are located in the same building) and the Bank team raised the risk of delaying the disaster recovery center to the Government of Albania for a long time.

- KPMG, Italy were hired as independent quality assurance and quality control experts to 
support the IPRO to supervise the supply and integration contract, to perform software quality assurance and quality control, define procedures for system final acceptance and guide the software development team. This was designed to add considerable value to the development of the ALBSReP system and lower the corresponding risks. This added value was not delivered as the contract with the IT supplier was terminated for lack of performance.

- The introduction of the ALBSReP system to the District Offices staff required training, not only on the IT system use, but also legal and procedural training. This training and associated support was limited and significantly reduced the effective use of the ALBSReP system.

- In August 2014, the contractors delivering the ICT infrastructure had their contract terminated due to non-performance on the integration component of their contract. The contractor has challenged this move by IPRO and the dispute is being managed initially through arbitration. No alternative source of support has been identified by IPRO, exposing IPRO to further risk.

\section{Summary}

The project benefits for the Albania Land Administration and Management Project come from seven channels: residential property market development, MSME development, productivity gains from e-governance, fiscal revenue gains from property taxation, fiscal savings from IPRO self-financing, municipal infrastructure development, and potential future savings from emergency response.

\section{Beneficiary Survey Results}

\section{Customer Satisfaction Surveys}

Three customer satisfaction surveys were conducted during the course of the project implementation. The main objective was to assess the project performance indicator for Component A: "IPRO customer satisfaction improved from very poor to very good"

The first Customer Satisfaction Survey was conducted in the period September - December 2012 and the final report was delivered in February 2011. The general level of client satisfaction was assessed to be "average". This rate of satisfaction is also reflected in the Monitoring Indicators table. The general conclusion of the Report was: Overall, we assess that IPRO regional offices have improved the quality of services for customers, by encouraging the development of a real estate market. However, we notice that there is room and opportunity for further improvement in the overall function of customers' services and increasing of security when performing transactions with immovable properties in favor of the national economy in general.

The second customer satisfaction survey was conducted in the period November 2012 January 2013. The final report was provided in March 2013.

According to the consultant's report we recommend improvements in the following areas:

\section{- Improving service quality:}

Time spent at IPRO service desks to obtain a service needs to be reduced. For this reason it is recommended an increase in the number of service desks that have 
direct contact with clients as well as proper training of recently hired staff. This would improve staff efficiency and would reduce the time of waiting in line. In addition, it should be noted that the staff work performance indicators does not currently exist. In this regard it is recommended the establishment of such performance indicators and their continuous monitoring. In April 2013, when IPRO turned into a self-financing institution, fees were more than doubled which might have contributed to the slight decrease in customer satisfaction levels to some extent. The rationale behind this might be that while fees for the same services were increased, the efficiency of service delivery did not match such an increase, failing to meet people's expectations about possible efficiency improvement due to higher fees. Overall, the perception that fees are high should be understood by taking into consideration that the economic situation has worsened overall (increase in unemployment for example), and taking into account that the increase in fees was not accompanied by the provision of a new service or faster service delivery.

In addition, the increase of fees was not based on a cost-based analysis. The establishment of fees should derive from a cost-based analysis, where the fees cover the overall service cost plus a specific margin. In the current situation, the revenues exceed to a great extent IPRO costs. Thus, it is recommended the conduction of a cost-based analysis, in order for the service fees to cover the basis cost elements and a small margin.

Another aspect that needs a specific attention is the free services that IPRO provides for public institutions. Currently the public institutions do not pay any fees for service delivery at IPRO. This means that the other customers take on the weight of paying for them. In this regard, it is recommended that public institutions, which benefit from free services from IPRO pay for these services. This would reduce the burden placed on private customers who have to compensate for this. Institutions exempted from paying for IPRO services could include budgeting institutions such as: the army, the police, the prosecution etc. The expenses of these institutions, which are estimated to be nonetheless small, could be paid by the government budget for example.

Another aspect that might change and it comes as e recommendation as well, is related to the annual fiscal profit of IPRO. Currently, IPRO functions as a selffinancing institution and the profit goes to the government budget at the end of the year. This means that the new fiscal year of IPRO starts with a balance sheet of zero profits.

In this situation it recommended that the profit that IPRO generates remains at IPRO and is used for further investments, improvements etc.

\section{- Access to Information and Public Awareness}

The results of the survey indicate that the information offices at IPRO remain the main source of information. This leads to long lines at IPROs and to longer waiting hours. To mitigate long lines and waiting hours IPRO should try to provide comparable information through other sources such as for example: media, online portal of IPRO etc. This would facilitate individuals living in more remote areas, for which it is difficult to travel to IPROs, so that they have access to information related to IPRO services as well. In this way time would be used more efficiently and the finalization of procedures would be made easier. All of this in turn would be translated into a higher level of customer satisfaction. In this regard, IPRO should work on raising 
the public awareness for using such sources.

More public awareness campaigns regarding first registration procedures are recommended, in order to encourage new customers to register their properties, especially in rural areas.

According to the results of the survey only a small number of customers have used the electronic registry, which calls for more campaigns for the purpose of informing customers about the benefits of using the electronic registry as a faster and costless service.

\section{- Increase of System Efficiency}

The further expansion of electronic services should continue and the implementation of the automatic registration system should be extended to all local IPROs, which would bring considerable improvement in timeframes of transactions finalizations.

\section{References}

European Commission. 2010. Opinion on Albania's Application for Membership of the European Union. Brussels, November 9.

European Commission. 2010. Albania 2010 Progress Report. Brussels, November 9

Economist Intelligence Unit. 1993. Country Report for Albania.

World Bank. 2006. Status of Land Reform and Property Markets in Albania. Tirana.

European Parliament, Directorate General External Polices of the European Union. 2008. Property Restitution in Albania. Brussels.

OSCE. 2003. Commentary on the Draft Law on Restitution and Compensation of Property.

Report by the EC EURALIUS project. 2010. Final Assessment Report on the Situation of Property Rights in Albania. Tirana.

Republic of Albania Council of Ministers. 2009. National Strategy for Development and Integration: Progress Report 2008. November.

World Bank. 2006. Status of Land Reform and Property Markets in Albania. World Bank: Tirana: appendix 12

Legal and Institutional Assessment, World Bank Integrated Coastal Zone Management and Clean-up Project.

Centre on Housing Rights and Evictions. 2002. Albania: Resolving the Question of Land and Property Restitution and Compensation. Report to the World Bank and OSCE.

Government of Albania. 2009. Draft Inter-Sectoral Strategy Reform in the Field of Property Rights.

Transparency International Albania. 2008. Corruption with Property: An Impediment to Sustainable Development.

MANOILESCU AND DOBRESCU V. ROMANIA AND RUSSIA; http://hudoc.echr.coe.int/sites/eng/pages/search.aspx?i=001-72683

Legal and Institutional Assessment, World Bank Integrated Coastal Zone Management and Clean-up Project .2010.

EBRD-World Bank. 2010. BEEPS 2008.

The Federal Service for State Registration, Cadaster and Cartography - ROSREESTR: https://rosreestr.ru/site/en/

\section{List of Legal Acts}

Constitution of Albania, adopted on November 28, 1998

Law $37 / 1945$

Law no. 4626, dated 24.12.1969, published in the Përmbledhës i Përgjithshëm I Legjislacionit në Fuqi të Republikës Popullore Socialiste të Shqipërisë, 1945-1985.

Volume 1, Publication of the Juridical Bureau of the Council of Ministers apparatus, Tirana 1986, pg. 255 
Law no. 5506, dated 28.12.1976, published in the Përmbledhës i Përgjithshëm i Legjislacionit në Fuqi të Republikës Popullore Socialiste të Shqipërisë, 1945-1985 Volume 1, Publication of the Juridical Bureau of the Council of Ministers apparatus, Tirana 1986, pg. 9.

Law No. 7491 of 29.4.1991 on the major constitutional provisions, as amended

Law No. 7512 of 10.8 .1991 on the regulation and the protection of private property, free initiative, private and independent economic activity and privatisation, as amended

Law No. 7501/1991, published in Official Journal no 5/1991, pg. 246.

Law No. 7652 of 23.12.1992 on the privatisation of state-owned flats

Law no.8312, of 26.3.1993, on undivided agricultural land

Law No.7848 dated 25.7.1994 on Expropriations in the public interest and acquisitions of immovable properties for temporary users

Law No. 7983 , of 27.7 .1995 on purchasing agricultural land, pastures and meadows

Law No. 8053, of 21.12.1995, on transfer of agricultural land in ownership without payment

Law no.8337, of 30.4 .1998 , on transferring into ownership the agricultural land, pastures and meadows

Law $7051 / 1999$

Law $9235 / 2004$, on restitution and compensation of property, amended

Law 10.207 dated 20.1.2010, published in official journal 194, December 2009.

Decree no. 4494/ Dated 31.3.1969

Decision of the Constitutional Court no 16, dated 17.4.2000

Decision No. 452, of 17.10.1992, on Restructuring of agricultural enterprises

Decision of the Assembly of the Republic of Albania No. 183, on the approval of the methodology on the valuation of immovable property that will be compensated and of the methodology to be used for compensation, Official Journal 33/2005, pg. 1219; published on 18.05.2005.

Decision 566/2006 of the Council of Ministers, on the organisation and functioning of the Property Restitution and Compensation Agency. See http://www.akkp.gov.al/

Decision of the Council of Ministers No. 816, dated 20.12.2006, for the approval of the prices for building sites, defined on the relevant map, for Tirana city and Kavaja district, published in the Official Journal no. 143 , dated 30.12 .2006 .

Decision 747/2006 of the Council of Ministers, published in Official Journal no. 121, dated 24.11.1006, pg. 4829. See Decision 653, dated 29.9.2007, For the approval of the prices for building sites as determined on the relevant maps, for the regions of Lezha, Dibra, Korca and Kukes,

Decision Nr.139, dated 13.2.2008 For the approval of the prices for building cites as determined on the relevant maps, for the regions of Fieri, Elbasan, Tirana, Vlora, Durres and Shkodra, regions. Published in the Official Journal no. 25, dated 25.02.2008.

Decision 1620/2008, Published in the Official Journal no. 196, dated 7.01.2009. 